\title{
"Fake News" is a Fake Notion
}

\section{Clarence W Thomas*}

Associate Professor, School of Mass Communications, Virginia Commonwealth University, USA

As a journalism Professor I often discuss the meaning and purpose of journalism with my students. Recently, the notion of "Fake News" has managed to sneak into our conversations as students have sought clarification. Many students seem puzzled and confused when discussing the term. They want to know what such a term is supposed to mean in light of their study and practice of journalism. In addition to my own students, I recently taught a group of journalism students from China. They were also concerned by the term and wondered how controls on journalism in their country could dare be questioned by Americans when we have "Fake News" in our country.

\section{As I tell my students, wake up! "Fake News" is a FAKE notion.}

The notion of "Fake News" was forced on America and the world by a presidential candidate (now President) who used and uses it as a verbal preemptive device designed to lessen and even diminish facts/ truth, which he considers to be detrimental to himself and/or his cause. Under such a notion, truth and facts are supposed to wither away and become replaced by "alternative fact." Under this notion, flip/flop then flop/flip are standard practices. Right is wrong and wrong is right. Yes is no, then no is yes, then no again.

Some say that journalism is the first draft of history.

Journalism (like history) is supposed to seek truth, nothing else.

Journalism, at least in America, is supposed to seek truth and provide that truth to society. Journalism in America is also supposed to be a watchdog for society, which keeps check of government, big business, etc. In turn, the truth provided by journalism should facilitate a better society.

The founding fathers of the United States understood the value of the press as a facilitator of a free society. Therefore, they made freedom of the press a prominent part of the First Amendment of the Constitution. They understood that the press, in an attempt to seek and provide truth, might be unpopular at times, but nonetheless needed.

According to President George Washington, "Our liberty depends on the freedom of the press, and that cannot be limited without being lost."

Benjamin Franklin noted, "If all printers were determined not to print anything till they were sure it would offend nobody, there would be very little printed."

President Thomas Jefferson commented, "When the press is free and every man able to read, all is safe." He also noted, "The basis of our government being the opinion of the people, the very first object should be to keep that right; and were it left to me to decide whether we should have a government without newspapers, or newspapers without a government, I should not hesitate a moment to prefer the latter. But I should mean that every man should receive those papers and be capable of reading them." Jefferson believed, "The press is the best instrument for enlightening the mind of man, and improving him as a rational, moral and social being."

The United States now faces a President who belittles and demonizes the press (journalism) through his use of the fake term called "Fake News."

As the story goes, if you knowingly let a snake into your house, and it bites and kills your family, you have no one to blame but yourself. Wake up America! Wake up journalists! "Fake News" is a FAKE notion.
*Corresponding author: Clarence W Thomas, Associate Professor, School of Mass Communications, Virginia Commonwealth University, USA, Tel: 804-8273772; E-mail: cwthomas@vcu.edu

Received October 30, 2017; Accepted Janaury 19, 2018; Published January 22 2018

Citation: Thomas CW (2018) "Fake News" is a Fake Notion. J Mass Communicat Journalism 8: 356. doi: 10.4172/2165-7912.1000356

Copyright: (C) 2018 Thomas CW. This is an open-access article distributed under the terms of the Creative Commons Attribution License, which permits unrestricted use, distribution, and reproduction in any medium, provided the original author and source are credited. 